\title{
Usability Testing of Senjang Muba Application Using System Usability Scale
}

\section{Pengujian Usability Aplikasi Senjang Muba Menggunakan System Usability Scale}

\author{
Ahmad Haidar Mirza', Dedi Irawan ${ }^{2}$ \\ ${ }^{1}$ Informatics Departement, Universitas Bina Darma, Palembang, Idnonesia \\ 2 Information System Department, Universitas Bina Darma, Palembang, Idnonesia \\ Email: ${ }^{1}$ haidarmirza@binadarma.ac.id,2dedi.irawan@binadarma.ac.id
}

\begin{abstract}
Abstrak
Aspek penting pengukuran kualitas aplikasi adalah usability. Tingkat usability dapat menentukan sejauh mana sebuah produk atau layanan dapat digunakan pengguna untuk mencapai tujuannya dan seberapa mudah dalam menggunakan antarmuka aplikasi tersebut. Aplikasi dengan tingkat usability yang tinggi biasanya akan memiliki pengguna yang banyak dan setia. Begitu juga sebaliknya, jika tingkat usability suatu aplikasi rendah pada akhirnya akan ditinggalkan oleh pengguna dan beralih ke aplikasi lain. Pada penelitian ini, aplikasi yang akan di analisa adalah aplikasi layanan pengaduan masyarakat di Kabupaten Musi Banyuasin yang bernama Aplikasi Saluran Elektronik Layanan Jaring Aspirasi dan Aduan Warga Musi Banyuasin atau Senjang Muba. Aplikasi ini menyediakan form untuk diisi oleh masyarakat yang ingin membuat pengaduan. Pengukuran usability melibatkan pengujian langsung pada sampel pengguna. Penelitian ini juga menggunakan kuesioner yang mengacu pada Standard Usability Questionnaires, yaitu System Usability Scale (SUS).
\end{abstract}

Kata Kunci: Usability, System Usability Scale (SUS), Aplikasi Senjang Muba

\section{PENDAHULUAN}

Fenomena akan kebutuhan teknologi dalam sektor pemerintahan kini semakin digalakkan. Pemerintah mulai membuat terobosan baru untuk memberikan layanan yang maksimal bagi warganya. Salah satu konsep yang sedang berkembang dengan mendasarkan penerapan teknologi informasi dan komunikasi dalam mengelola kota adalah smart city. Dapat diketahui bahwa konsep smart city merupakan ujung dari pengembangan konsep pembangunan dan pengelolaan kota berbasis teknologi informasi dan komunikasi [1]. 
Perencanaan smart city adalah agenda global sebagai respon konseptual dan praktis terhadap berbagai krisis perkotaan. Konsep smart city atau kota cerdas diyakini bisa menyelesaikan berbagai masalah umum perkotaan seperti kemacetan, kecelakaan, bencana alam, kelangkaan sumber daya, pungli, limbah, polusi dan beragam masalah fisik lainnya. Permasalahan kota juga bukan hanya dari segi fisik saja, ketidakpercayaan masyarakat terhadap pemerintah dapat memicu timbulnya masalah-masalah sosial yang berkaitan dengan masing-masing pemangku kepentingan. Sehingga dalam menyelesaikan permasalahan fisik ditambah dengan permasalahan sosial, serta untuk menjaga performanya, pemerintah membutuhkan peran dari berbagai pihak.

Kabupaten Musi Banyuasin saat ini tengah bergerak menuju smart city dalam penyelenggaraan pemerintahannya. Pemerintah kabupaten melalui Dinas Komunikasi dan Informatika (Dinkominfo) sedang berinovasi menciptakan berbagai terobosan untuk mendukung terwujudnya konsep smart city. Beberapa diantaranya adalah dengan disusunnya Digital Security System, membangun Command Centre Room, Muba Call Centre, menggalakkan Program Internet Desa dan menghadirkan Aplikasi Saluran Elektronik Layanan Jaring Aspirasi dan Aduan Warga Musi Banyuasin (Senjang Muba).

Senjang Muba adalah aplikasi resmi dari Pemerintah Kabupaten Musi Banyusasin, Sumatera Selatan. Aplikasi ini diperuntukan bagi masyarakat dalam memperoleh informasi seputar Kabupaten Musi Banyuasin dan sebagai media penyampaian aspirasi berupa, kritik, saran maupun keluhan masyarakat terhadap kinerja pemerintah kabupaten setempat. Aplikasi Senjang Muba resmi diluncurkan pada September 2017, menyediakan akses yang luas kepada masyarakat melalui aplikasi mobile berupa android. Data Senjang Muba per Agustus 2018 menunjukkan sudah lebih dari 500 pengunduh aplikasi dengan jumlah aduan sebanyak 35 kasus.

Aplikasi Senjang Muba baik pada saat pembuatan maupun pada saat digunakan tidak terlepas dari faktor kemudahan penggunaan (usability). Pengujian usability perlu dilakukan untuk menilai aplikasi dari segi kemudahan, ketepatan, kesalahan dan kepuasan pengguna. Usability aplikasi penting untuk diperhatikan agar pemakai yang mengimplementasikan aplikasi tersebut merasa mudah untuk menggunakannya, memperoleh informasi yang diperlukan dan tertarik untuk masuk lebih dalam pada aplikasi. Untuk melakukan pengujian usability, metode yang dapat digunakan diantaranya adalah heuristic evaluation (HE) dan system usability scale (SUS). Kedua metode pengujian ini berfokus pada penilaian antarmuka aplikasi, namun berbeda pada tingkat penguji (evaluator) [2]. Metode Heuristic evaluation (HE) dilakukan oleh ahli (expert) dalam proses pengujian antarmuka aplikasi. Sedangkan system usability scale (SUS) dilakukan oleh pengguna akhir (end user) dalam proses pengujian antarmuka aplikasi. Untuk itu 
dalam melakukan usability testing pada aplikasi layanan pengaduan masyarakat di Kabupaten Musi Banyuasin digunakan system usability scale (SUS) sebagai instrumen pengujian. Pemanfaatan metode pengujian SUS dalam usability testing pada aplikasi layanan pengaduan masyarakat di Kabupaten Musi Banyuasin diharapkan dapat memberikan hasil pengujian yang akurat.

Dari uraian permasalahan di atas, maka penulis dapat merumuskan masalah yang ada untuk dijadikan titik tolak pada pembahasan dalam penulisan penelitian ini. Adapun rumusan masalah yang ada dalam penelitian ini adalah "Bagaimana melakukan pengujian usability testing pada aplikasi layanan pengaduan masyarakat di Kabupaten Musi Banyuasin dengan teknik system usability scale?"

\section{METODOLOGI PENELITIAN}

Dalam melakukan penelitian ini terdapat beberapa meotode yang digunakan sebagai upata penyelesaian penelitian, dapat dijelaskan sebagai berikut:

\subsection{Metode Pengumpulan Data}

Dalam pengumpulan data untuk penelitian usability testing pada aplikasi layanan pengaduan masyarakat di Kabupaten Musi Banyuasin, digunakan beberapa cara, yaitu:

1) Wawancara: Wawancara merupakan percakapan dengan maksud tertentu dan sebagai bentuk komunikasi langsung antara peneliti dengan responden. Adapun narasumber dalam penelitian ini yaitu Kepala dan Pegawai Dinas Komunikasi dan Informatika Kabupaten Musi Banyuasin dengan konteks wawancara mengenai histori dan gambaran-gambaran secara umum tentang aplikasi layanan pengaduan masyarakat di Kabupaten Musi Banyuasin. Selain itu, peneliti juga melakukan wawancara dengan responden terkait kepuasan dan perasaan responden atas penggunaan aplikasi.

2) Observasi: Observasi merupakan suatu kegiatan mencari data yang dapat digunakan untuk memberikan suatu kesimpulan atau diagnosis [3]. Observasi atau pengamatan merupakan metode pengumpulan data dimana peneliti atau klaboratornya mencatat informasi sebagaimana yang mereka saksikan selama penelitian [4]. Adapun observasi yang dilakukan peneliti berfokus pada pengelolaan data aplikasi oleh administrator yang juga merupakan pegawai Dinas Komunikasi dan Informatika Kabupaten Musi Banyuasin.

3) Kuesioner, peneliti melakukan survei dengan bentuk menyebarkan kuesioner. Kuesioner terdiri dari beberapa pernyataan untuk melakukan uji ketergunaan (usability testing) terkait kepuasan responden dan tingkat 
kemudahan penggunaan aplikasi layanan pengaduan masyarakat di Kabupaten Musi Banyuasin yang dirasakan oleh responden. Hasil data kuesioner akan dideskripsikan untuk dievaluasi.

\subsection{Metode System Usability Scale}

Langkah-langkah dalam melakukan uji ketergunaan. Langkah-langkah yang dikemukakan adalah sebagai berikut [5]:

1) Planning a Usability Test, Perencanaan uji ketergunaan merupakan salah satu faktor penting di dalam penelitian, karena faktor ini akan menentukan keberhasilan pengujian di lapangan. Di dalam perencanaan ini perlu mencakup tujuan, permasalahan profil reponden, daftar soal, peralatan yang akan digunakan dan data yang harus dikumpulkan.

2) Selecting a representative sample and recruiting partipipants. Penetapan responden juga termasuk elemen penting dalam pengujian. Dalam memilih dan menetapkan responden sebaiknya disesuaikan dengan ciri dan kondisi responden yang akan menggunakan aplikasi ataupun sistem.

3) Preparing the test materials and actual test environment. Menyiapkan peralatan untuk melakukan pengujian, mulai dari kuesioner, alat tulis hingga alat dokumentasi.

4) Conduction the usability test, yakin terhadap pelaksanaan pengujian.

5) Debriefing the Participant. Memberikan pengarahan kepada responden dengan maksud untuk mengetahui tentang semua yang telah dilakukan responden selama penguiian.

6) Analyzing the data of the usability test. Analisis data pengujian, dimaksudkan untuk pengelompokan data sesuai dengan kategori data yang telah terkumpul.

7) Reporting the result and making recommendations to improve the design and effectivess of the product. Pembuatan laporan hasil pengujian, hendaknya memuat daftar permasalahan yang terjadi dan usulan untuk perbaikan dan pengembangan aplikasi.

Berdasarkan langkah-langkah yang telah diuraikan, maka desain penelitian dalam penelitian ini dapat dijelaskan sebagai berikut [6]:

1) Memilih objek, langkah ini adalah proses penentuan objek yang akan diteliti, yaitu Aplikasi Saluran Elektronik Layanan Jaring Aspirasi dan Aduan Warga Musi Banyuasin (Senjang Muba).

2) Memilih responden untuk melakukan pengisian kuisioner berdasarkan jumlah sampel yang telah ditentukan.

3) Mempresentasikan tugas kepada responden, langkah ini memberikan penjelasan kepada responden bahwa yang diuji bukan responden tetapi 
Vol. 2, No. 2, September 2020

objek penelitian dan memberikan penjelasan bagaimana proses pengisian kuesioner.

4) Memberikan tugas kepada responden, yaitu meminta responden untuk mengoperasikan atau menjalakan fungsi tombol yang ada di Aplikasi Senjang Muba [7].

5) Pengisian kuesioner oleh responden, responden memberikan jawaban untuk kuesioner sesuai dengan yang dialami oleh responden. Rancangan awal daftar pernyataan kesioner penelitian seperti yang terlihat pada Tabel 1.

Tabel 1. Instrumen Pengujian SUS [8]

\begin{tabular}{|c|l|c|}
\hline No & \multicolumn{1}{|c|}{ Pernyataan } & Skala \\
\hline 1 & $\begin{array}{l}\text { Saya pikir bahwa saya akan lebih sering menggunakan } \\
\text { aplikasi ini }\end{array}$ & $1 \mathrm{~s} / \mathrm{d} 5$ \\
\hline 2 & $\begin{array}{l}\text { Saya menemukan bahwa aplikasi ini seharusnya tidak } \\
\text { dibuat serumit ini }\end{array}$ & $1 \mathrm{~s} / \mathrm{d} 5$ \\
\hline 3 & $\begin{array}{l}\text { Saya beranggapan bahwa aplikasi ini mudah untuk } \\
\text { digunakan }\end{array}$ & $1 \mathrm{~s} / \mathrm{d} 5$ \\
\hline 4 & $\begin{array}{l}\text { Saya pikir bahwa saya akan membutuhkan bantuan dari } \\
\text { orang teknis untuk dapat menggunakan aplikasi ini }\end{array}$ & $1 \mathrm{~s} / \mathrm{d} 5$ \\
\hline 5 & $\begin{array}{l}\text { Saya menemukan berbagai fungsi di aplikasi ini } \\
\text { diintegrasikan dengan baik }\end{array}$ & $1 \mathrm{~s} / \mathrm{d} 5$ \\
\hline 6 & $\begin{array}{l}\text { Saya menemukan banyak ketidaksesuaian dalam aplikasi } \\
\text { ini }\end{array}$ & $1 \mathrm{~s} / \mathrm{d} 5$ \\
\hline 7 & $\begin{array}{l}\text { Saya membayangkan bahwa kebanyakan orang dapat } \\
\text { belajar dengan mudah dalam menggunakan aplikasi ini }\end{array}$ & $1 \mathrm{~s} / \mathrm{d} 5$ \\
\hline 8 & $\begin{array}{l}\text { Saya beranggapan aplikasi ini sangat sulit untuk } \\
\text { digunakan }\end{array}$ & $1 \mathrm{~s} / \mathrm{d} 5$ \\
\hline 9 & $\begin{array}{l}\text { Saya merasa sangat percaya diri untuk menggunakan } \\
\text { aplikasi ini }\end{array}$ & $1 \mathrm{~s} / \mathrm{d} 5$ \\
\hline 10 & $\begin{array}{l}\text { Saya perlu belajar banyak hal sebelum bisa memulai } \\
\text { menggunakan aplikasi ini }\end{array}$ & $1 \mathrm{~s} / \mathrm{d} 5$ \\
\hline
\end{tabular}

6) Analisa jawaban dari responden terhadap kuesioner penelitian usability testing Aplikasi Senjang Muba.

7) Dari evaluasi yang dilakukan akan didapat informasi mengenai kelebihan dan kekurangan Aplikasi Senjang Muba yang sekarang ini menggunakan teknik usability testing.

8) Membuat laporan dari evaluasi dan memberikan rekomendasi [9]. 
Vol. 2, No. 2, September 2020

p-ISSN: 2656-5935 http://journal-isi.org/index.php/isi

e-ISSN: 2656-4882

\subsection{Objek Pengukuran}

Tampilan antarmuka Aplikasi Saluran Elektronik Layanan Jaring Aspirasi dan Aduan Warga Musi Banyuasin (Senjang Muba) yang dijalankan pada smartphone berbasis android dapat dilihat seperti di bawah ini:

1) Tampilan splash screen logo.

Saat pengguna pertama kali membuka Aplikasi Senjang Muba, maka yang terlihat adalah tampilan splash screen logo aplikasi selama kurang lebih dua detik, seperti yang terlihat pada Gambar 1.

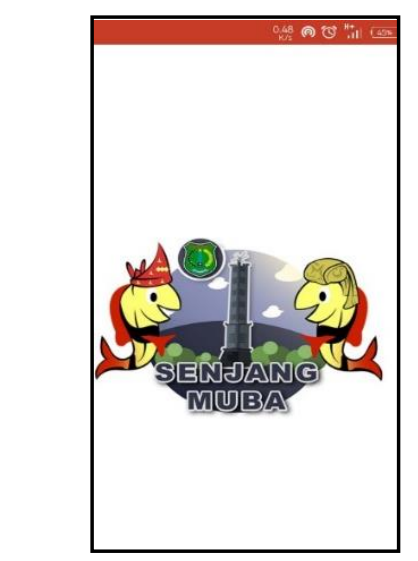

Gambar 1. Splash Screen Logo

2) Menu Beranda

Setelah menampilkan splash screen logo, kemudian pengguna langsung diarahkan ke Menu Beranda seperti yang diperlihatkan pada Gambar 2.

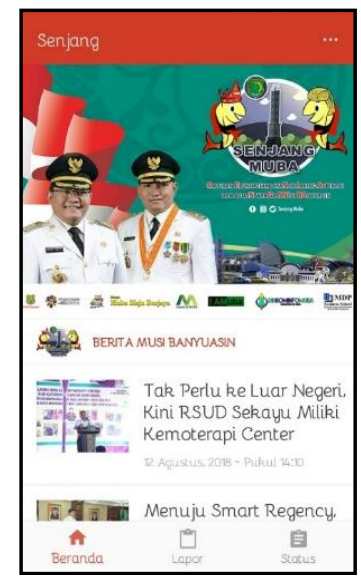

Gambar 2. Tampilan Menu Beranda 
Vol. 2, No. 2, September 2020

p-ISSN: 2656-5935 http://journal-isi.org/index.php/isi

e-ISSN: 2656-4882

Pada Menu Beranda terdapat header berupa gambar pasangan Bupati dan Wakil Bupati Musi Banyuasin serta logo dan nama aplikasi. Pengguna juga disajikan dengan pilihan berita seputar Kabupaten Musi Banyuasin yang ter-update. Untuk membaca berita selengkapnya, pengguna dapat mengklik judul berita yang mereka sukai, lalu akan muncul tampilan seperti yang terlihat pada Gambar 3. Untuk saat ini pengguna aplikasi hanya bisa membaca berita yang disajikan, belum tersedia tombol share untuk membagikan link berita ke media sosial dan kolom untuk menambahkan komentar juga belum tersedia.

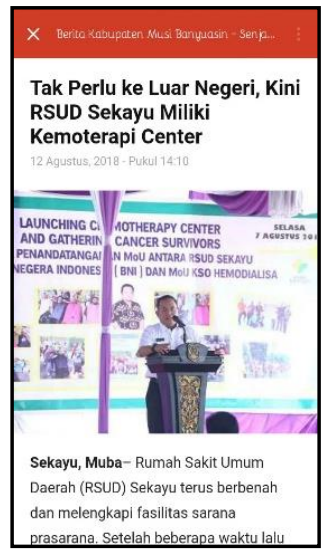

Gambar 3. Tampilan baca berita

3) Menu Lapor

Selanjutnya untuk membuat pengaduan, pengguna dapat memilih Menu Lapor dan mengisi form yang tersedia. Semua data yang terdiri dari foto lokasi, Judul Laporan, Nomor Induk Kependudukan (NIK), Nama Pelapor, Kontak Pelapor, dan Permasalahan harus diisi secara lengkap. Setelah mengisi form secara lengkap, seperti yang terlihat pada Gambar 4.4, pengguna dapat mengirim laporan dengan mengklik tombol Kirim.
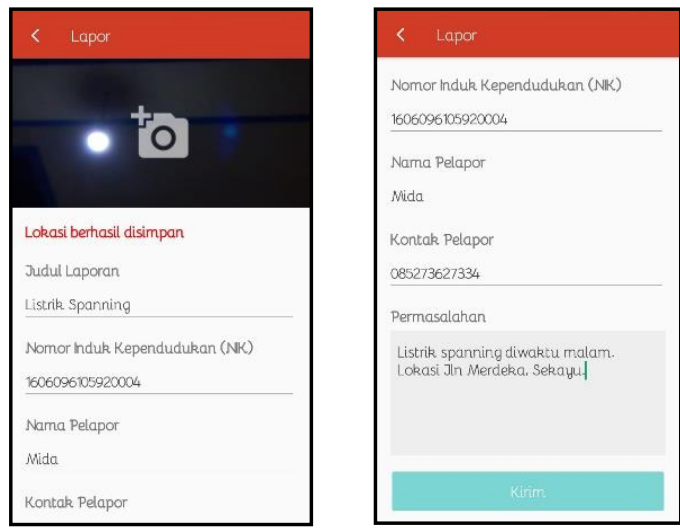

Gambar 4. Form pada Menu Lapor 
Vol. 2, No. 2, September 2020

p-ISSN: 2656-5935 http://journal-isi.org/index.php/isi

e-ISSN: 2656-4882

Namun apabila form tidak diisi secara lengkap, laporan tidak dapat dikirim dan akan muncul peringatan untuk melengkapi data seperti pada Gambar 5.

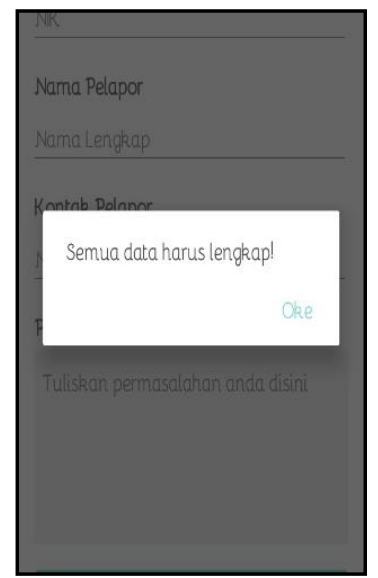

Gambar 5. Jendela peringatan untuk melengkapi data

4) Menu Status

Laporan yang telah dikirim akan muncul pada Menu Status seperti yang terlihat pada Gambar 6.

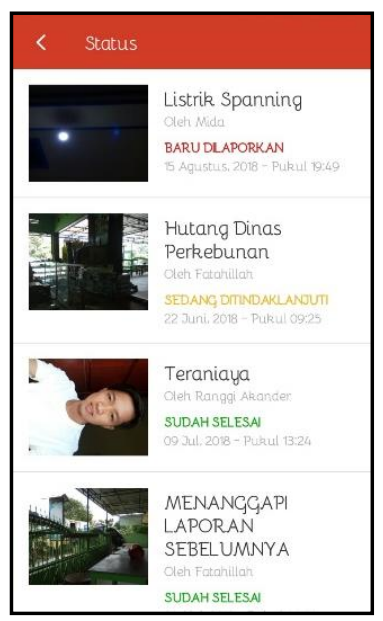

Gambar 6. Tampilan Menu Status

Ada 3 (tiga) jenis proses terkait status laporan yang telah dikirim oleh pengguna, yaitu Baru Dilaporkan, Sedang Ditindaklanjuti dan Sudah Selesai. Status Baru Dilaporkan diperuntukkan bagi aduan yang baru dikirim oleh pengguna dan belum mendapat tanggapan dari dinas terkait. Apabila dinas terkait sudah mulai menanggapi, status aduan akan berubah menjadi Sedang Ditindaklanjuti. Status 
Vol. 2, No. 2, September 2020

p-ISSN: 2656-5935 http://journal-isi.org/index.php/isi e-ISSN: 2656-4882

Sudah Selesai akan muncul apabila permasalahan yang dikirimkan masyarakat telah mendapat solusi dari dinas terkait.

Untuk melihat detail status aduan, pengguna dapat mengklik judul aduan yang terdapat pada Menu Status. Kemudian akan ditampilkan foto, nama pelapor, detail permasalahan, dinas terkait, dan status laporan seperti yang terlihat pada Gambar 7 dan Gambar 8.

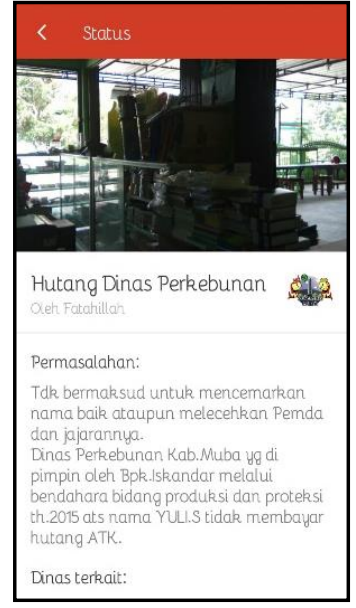

Gambar 7. Detail aduan masyarakat

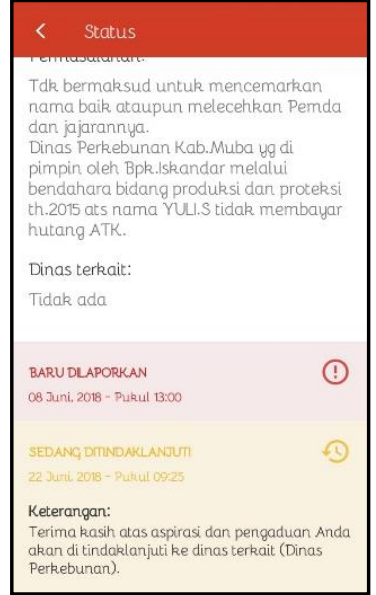

Gambar 8. Status aduan masyarakat

Selama proses perubahan status aduan masyarakat, dari Baru Dilaporkan, menjadi Sedang Ditindaklanjuti hingga status Sudah Selesai, administrator Aplikasi Senjang Muba berperan sebagai penghubung antara masyarakat dan instansi terkait yang memiliki wewenang dalam menanggapi permasalahan. Misalnya permasalahan listrik, maka administrator Aplikasi Senjang Muba akan mengkoordinir pihak PLN untuk memberikan tanggapan terkait permasalahan yang dilaporkan. Setelah ada tindak lanjut berupa jawaban tertulis maupun pengecekan langsung di lapangan, pihak PLN wajib melaporkan aktifitasnya ke administrator aplikasi untuk kemudian disampaikan kepada masyarakat melalui media Aplikasi Senjang Muba. Untuk saat ini, perubahan status pada aplikasi masih harus dicek secara manual dengan membuka Aplikasi Senjang Muba.

\section{HASIL DAN PEMBAHASAN}

\subsection{Karateristik Responden}

Kuesioner yang disebar secara langsung pada tanggal 31 Agustus 2018, didistribusikan kepada 100 (seratus) responden. Responden yang dipilih merupakan mereka yang setidaknya pernah menggunakan Aplikasi Saluran 
Vol. 2, No. 2, September 2020

p-ISSN: 2656-5935 http://journal-isi.org/index.php/isi

e-ISSN: 2656-4882

Elektronik Layanan Jaring Aspirasi dan Aduan Warga Musi Banyuasin (Senjang Muba). Hal ini memudahkan proses evaluasi dari pengalaman responden terhadap Aplikasi Senjang Muba. Data persebaran responden dapat dilihat pada Gambar 9 dan Gambar 10.

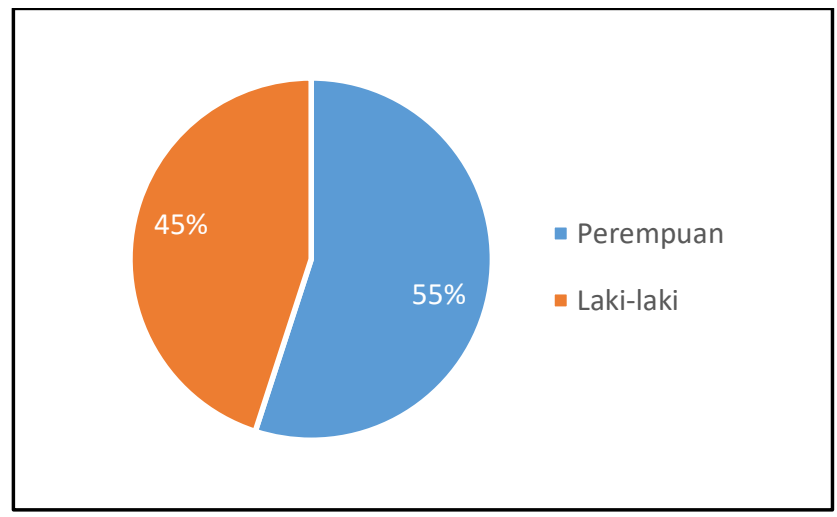

Gambar 9. Diagram karakteristik responden berdasarkan jenis kelamin

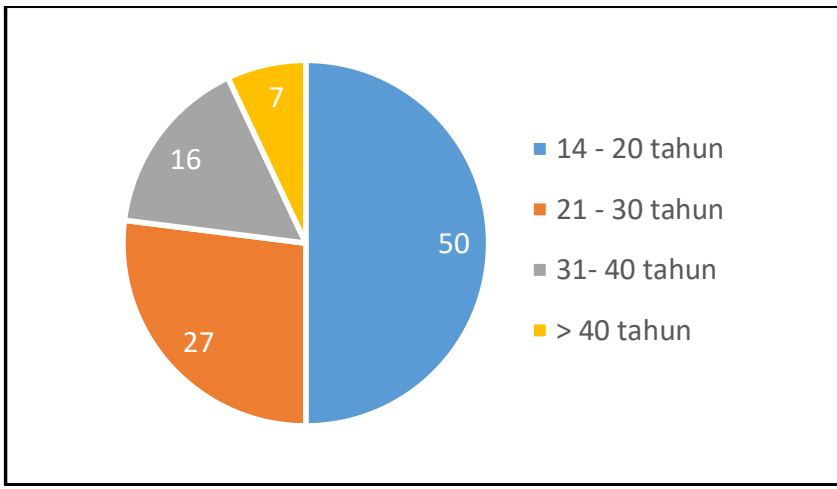

Gambar 10. Diagram karakteristik responden berdasarkan umur

Gambar 9 menunjukkan diagram persebaran demografi responden yang terlibat dalam kuesioner penelitian usability testing Aplikasi Senjang Muba dengan karakteristik responden berdasarkan jenis kelamin. Sedangkan Gambar 10 menunjukkan perbandingan jumlah responden berdasarkan usia. Berdasarkan jenis kelamin, responden yang memberikan penilaian terdiri dari 45 (empat puluh lima) responden berjenis kelamin laki-laki dan 55 (lima puluh lima) responden berjenis kelamin perempuan. Jumlah ini menunjukkan bahwa sebaran kuesioner antara jenis kelamin laki-laki dan perempuan cukup seimbang, yaitu 45\% responden berjenis kelamin laki-laki dan 55\% responden berjenis kelamin perempuan. Sedangkan berdasarkan umur, terdapat 50 responden berusia antara 14 sampai dengan 20 tahun, usia 21 sampai dengan 30 tahun berjumlah 27 responden, 31 sampai dengan 40 tahun sebanyak 16 responden dan 7 responden 
Vol. 2, No. 2, September 2020

p-ISSN: 2656-5935 http://journal-isi.org/index.php/isi

e-ISSN: 2656-4882

berusia diatas 40 tahun. Artinya sebanyak 50\% merupakan mereka yang berusia dibawah 20 tahun dan 43\% merupakan responden yang berusia antara $21-40$ tahun. Karakteristik responden berdasarkan pekerjaan dapat dilihat seperti pada Gambar 11.

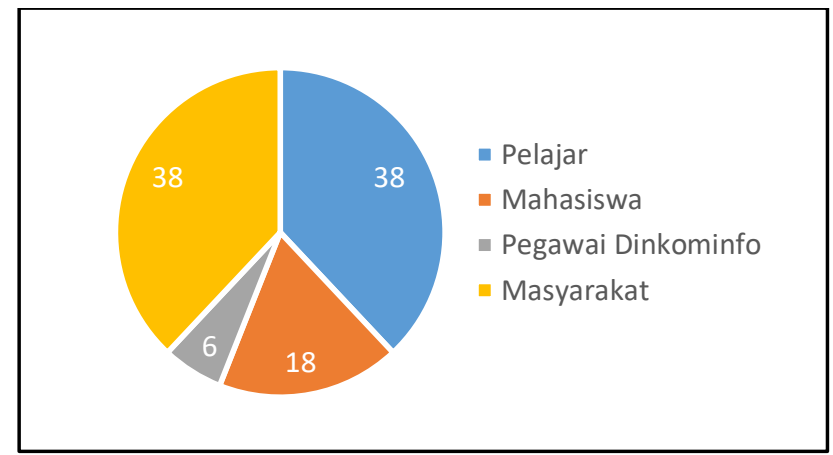

Gambar 11. Diagram karakteristik responden berdasarkan pekerjaan

Dari segi pekerjaan, sebagian besar responden masih berstatus sebagai pelajar dan masyarakat umum. Kelompok masyarakat umum merupakan gabungan responden yang bekerja sebagai dosen, pegawai PT, wirausaha, wartawan, honorer dan PNS di instansi selain Dinas Komunikasi dan Informatika Kabupaten Musi Banyuasin. 18 responden masih berstatus mahasiswa dan 6 responden merupakan pegawai di Dinas Komunikasi dan Informatika Kabupaten Musi Banyuasin.

Selain usia, jenis kelamin dan pekerjaan, diambil juga data lamanya penggunaan smartphone oleh responden, waktu mengakses internet setiap hari, tujuan responden mengakses internet dan intensitas penggunaan Aplikasi Senjang Muba dari tiap responden. Diagram karakteristik responden berdasarkan pengalaman menggunakan smartphone dapat dilihat pada Gambar 12.

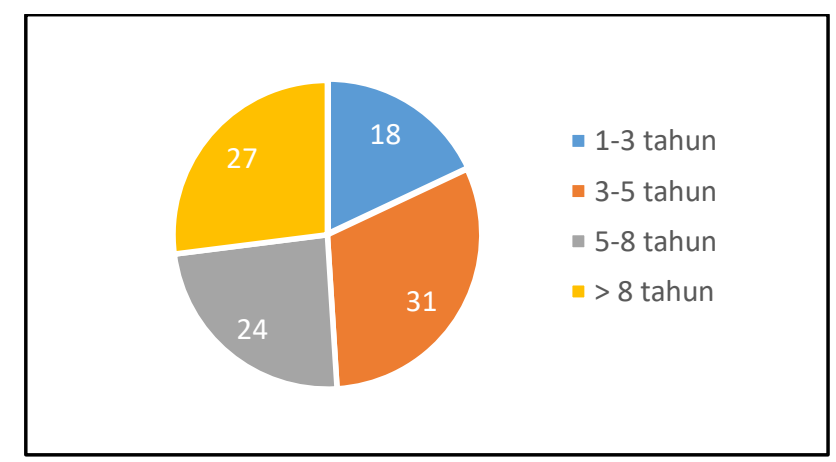

Gambar 12. Diagram karakteristik responden berdasarkan pengalaman menggunakan smartphone 
Jawaban tertinggi responden mengenai pengalaman menggunakan smartphone yaitu selama 3 sampai 5 tahun sebanyak 31 responden. Sebanyak 27 responden memiliki pengalaman menggunakan smartphone selama lebih dari 8 tahun. 24 diantaranya memiliki pengalaman menggunakan smartphone selama 5 sampai 8 tahun dan 18 responden memiliki pengalaman menggunakan smartphone antara 1 sampai 3 tahun.

Sedangkan banyaknya waktu yang dialokasikan oleh sebagian besar responden untuk mengakses internet setiap hari adalah selama lebih dari 3 jam. Tujuan penggunaan internet yang paling banyak dilakukan adalah untuk mengakses media sosial sebanyak $36 \%$ dan mencari informasi dengan cara searcbing atau browsing oleh 30\% responden. Ada juga yang memanfaatkan internet untuk mengupload dan men-download data sebanyak 23 responden. Selebihnya, 11 responden memanfaatkan internet untuk bermain game. Gambar 13 mendeskripsikan persebaran tujuan penggunaan internet oleh tiap responden.

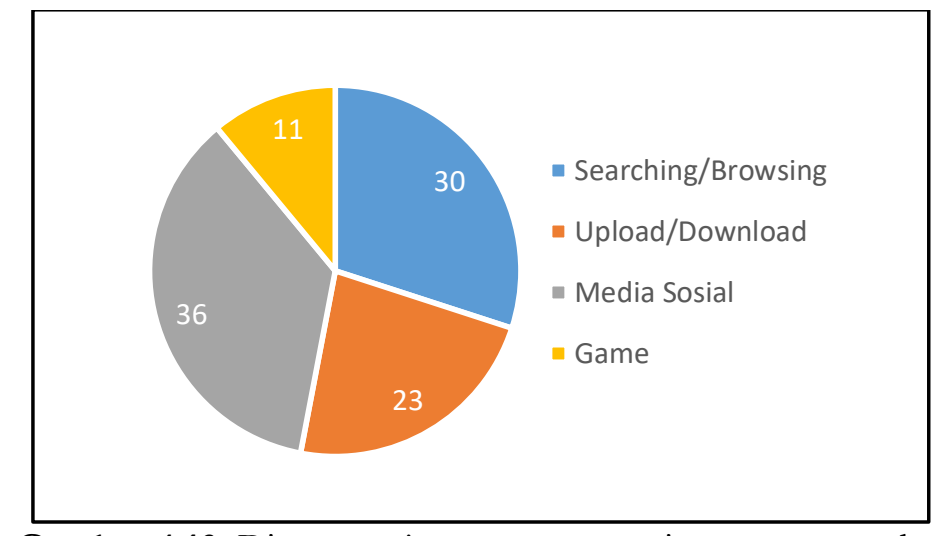

Gambar 4.13. Diagram tujuan penggunaan internet responden

Berdasarkan intensitas penggunaan Aplikasi Senjang Muba, sebanyak 72 responden menyatakan baru pertama kali menggunakan aplikasi. Hal ini menunjukkan kurangnya sosialisasi terhadap penerapan aplikasi layanan pengaduan masyarakat di Kabupaten Musi Banyuasin. Untuk penggunaan aplikasi yang lebih dari 10 kali dilakukan oleh 6 responden dimana 4 diantaranya merupakan Pegawai di Dinas Komunikasi dan Informatika Kabupaten Musi Banyuasin.

Pemilihan responden berdasarkan karakteristik di atas dapat dilihat secara nyata dan objektif. Selain itu, penetapan jumlah responden dan karakteristik responden tersebut dapat menggambarkan keadaan pengguna akhir yang akan memanfaatkan Aplikasi Senjang Muba karena telah mewakili dari masing-masing karakteristik pengguna akhir. 
Vol. 2, No. 2, September 2020

p-ISSN: 2656-5935 http://journal-isi.org/index.php/isi

e-ISSN: 2656-4882

\subsection{Hasil Analisis Data Kuesioner}

Perhitungan dilakukan dengan menghitung nilai skor untuk setiap pernyataan. Nilai skor dihitung dengan menggunakan perhitungan SUS yang sudah dibahas pada sub bab 2.2.4. Rekapitulasi hasil penilaian responden terhadap Aplikasi Saluran Elektronik Layanan Jaring Aspirasi dan Aduan Warga Musi Banyuasin (Senjang Muba) sebagai sarana menyampaikan aspirasi masyarakat di Kabupaten Musi Banyuasin dapat dilihat pada Tabel 4.1.

Tabel 4.1. Rekapitulasi hasil penilaian responden

\begin{tabular}{|c|c|c|c|c|c|c|c|c|c|c|c|c|}
\hline \multirow[t]{2}{*}{ Res } & \multicolumn{10}{|c|}{ Pernyataan } & \multirow[t]{2}{*}{ Jmlh } & \multirow{2}{*}{$\begin{array}{l}\text { Jmlh } \\
\times 2.5 \\
\end{array}$} \\
\hline & 1 & 2 & 3 & 4 & 5 & 6 & 7 & 8 & 9 & 10 & & \\
\hline 1 & 3 & 3 & 3 & 3 & 4 & 3 & 4 & 4 & 4 & 1 & 32 & 80 \\
\hline 2 & 3 & 3 & 3 & 4 & 2 & 3 & 3 & 3 & 4 & 3 & 31 & 77.5 \\
\hline 3 & 3 & 3 & 3 & 3 & 4 & 3 & 4 & 3 & 4 & 1 & 31 & 77.5 \\
\hline 4 & 4 & 4 & 2 & 4 & 4 & 4 & 4 & 4 & 4 & 4 & 38 & 95 \\
\hline 5 & 2 & 3 & 3 & 3 & 3 & 3 & 3 & 3 & 3 & 2 & 28 & 70 \\
\hline 6 & 2 & 2 & 2 & 2 & 2 & 2 & 2 & 2 & 2 & 2 & 20 & 50 \\
\hline 7 & 4 & 4 & 3 & 2 & 4 & 4 & 4 & 3 & 3 & 1 & 32 & 80 \\
\hline 8 & 3 & 3 & 3 & 1 & 3 & 3 & 3 & 3 & 3 & 0 & 25 & 62.5 \\
\hline 9 & 1 & 3 & 1 & 3 & 1 & 3 & 1 & 3 & 1 & 3 & 20 & 50 \\
\hline$\ldots$ & & & & & & & & & & & & \\
\hline 96 & 4 & 3 & 4 & 2 & 4 & 2 & 4 & 4 & 3 & 3 & 33 & 82.5 \\
\hline 97 & 3 & 3 & 3 & 2 & 2 & 3 & 3 & 2 & 3 & 2 & 26 & 65 \\
\hline 98 & 4 & 4 & 4 & 4 & 4 & 4 & 3 & 3 & 3 & 1 & 34 & 85 \\
\hline 99 & 2 & 1 & 1 & 1 & 3 & 2 & 2 & 2 & 2 & 0 & 16 & 37.5 \\
\hline 100 & 4 & 3 & 3 & 4 & 4 & 3 & 3 & 2 & 2 & 2 & 30 & 75 \\
\hline & & & & & 10 & & & & & & & 100 \\
\hline
\end{tabular}

Selanjutnya adalah menentukan nilai rata - rata dari penilaian responden. Secara umum, dimana dari 100 (seratus) responden didapat jumlah nilai sebesar 7012,5 (tujuh ribu dua belas koma lima) dan di bagi 100 (seratus), maka nilai rata - rata yang didapat adalah 70 (tujuh puluh). Setelah mendapatkan hasil akhir penilaian responden maka selanjutnya adalah menentukan grade hasil penilaian. Dari dua cara penentuan hasil penilaian yang telah diuraikan pada bab sebelumnya, maka dapat dilihat hasil penilaian sebagai berikut :

\section{1) Acceptability, Grade Scale dan Adjective Rating:}

Penentuan Acceptability, grade scale dan adjective rating digunakan untuk melihat sejauh mana perspective pengguna terhadap Aplikasi Senjang Muba. Untuk menentukan Acceptability, grade scale dan adjective rating maka dilakukan perbandingan hasil penilaian rata-rata responden sebesar 70 (tujuh puluh) dengan 
ketentuan penilaian seperti pada Gambar 2.4. Dengan demikian berdasarkan hasil perhitungan rata-rata skor SUS dari seluruh responden, maka Aplikasi Saluran Elektronik Layanan Jaring Aspirasi dan Aduan Warga Musi Banyuasin (Senjang Muba) telah layak dan diterima. Karena Aplikasi Senjang Muba berada pada kategori Acceptable secara Acceptability Range. Namum Aplikasi Senjang Muba masih perlu banyak pengembangan untuk meningkatkan kemudahan penggunaan oleh pengguna akhir. Hal ini dikarenakan Aplikasi Senjang Muba berada pada kategori C untuk tingkat Grade Scale dan tingkat Adjective Rating masuk dalam kategori $O K$.

\section{2) SUS Skor Percentile Rank:}

Berdasarkan ketentuan penentuan hasil penilaian SUS skor percentile rank, maka hasil penilaian responden terhadapat Aplikasi Senjang Muba sebesar 70 (tujuh puluh) berada pada grade C. Nilai Aplikasi Senjang Muba cukup baik untuk dijadikan sebagai alat pendukung layanan pengaduan masyarakat di Kabupaten Musi Banyuasin, namun dengan beberapa pengembangan lebih lanjut untuk meningkatkan minat pengguna dalam mengoperasikan aplikasi tersebut.

Dari dua proses penentuan hasil penelitian yang telah dilakukan baik secara acceptability, grade scale dan adjective rating maupun secara SUS skor percentile rank dapat dilihat perbedaan dari hasil akhir penilaian. Kondisi tersebut disebabkan adanya perbedaan sudut pandang dalam proses penentuan hasil penilaian. Penentuan pertama dilakukan berdasarkan acceptability, grade scale dan adjective rating dimana satu sama lain berkaitan, sedangkan SUS skor percentile rank hanya melihat dari sisi rank saja. Namun secara umum hasil penilaian reponden terhadap antarmuka Aplikasi Senjang Muba dapat dikatakan cukup baik untuk dapat dimanfaatkan oleh pengguna akhir.

\section{KESIMPULAN}

Dari bebagai tahapan penelitian yang sudah dilakukan, maka penulis menyimpulkan beberapa poin yang dapat disimpulkan. Poin-poin tersebut dapat dijabarkan sebagai berikut:

1) Belum pernah dilakukan penelitian dari segi usability untuk aplikasi layanan pengaduan masyarakat di Kabupaten Musi Banyuasin dalam hal ini Aplikasi Saluran Elektronik Layanan Jaring Aspirasi dan Aduan Warga Musi Banyuasin (Senjang Muba). Adanya penelitian yang dilakukan secara kualitatif dan kuantitatif memberikan banyak data baru mengenai kenyamanan penggunaan Aplikasi Senjang Muba selama ini.

2) Dari hasil penelitian yang telah dilakukan terhadap Aplikasi Senjang Muba menggunakan metode System Usability Scale (SUS), dapat disimpulkan bahwa SUS dapat dijadikan sebagai alat evaluasi penilaian 
aplikasi yang terukur dan terstruktur secara akurat. Memiliki beragam cara dalam menentukan hasil evaluasi penilaian seperti yang diperlihatkan ketika melakukan evaluasi penilaian Aplikasi Senjang Muba. Dari hasil evaluasi penilaian yang dilakukan terhadap Aplikasi Senjang Muba mendapatkan skor 80 yang berarti Aplikasi Senjang Muba dinyatakan acceptable termasuk dalam grade B dengan rating excellent. Hasil penilaian SUS skor percentile rank juga menunjukkan Aplikasi Senjang Muba berada pada grade B. Dengan kata lain, Aplikasi Senjang Muba layak untuk digunakan oleh pengguna akhir sebagai media pendukung layanan pengaduan masyarakat di Kabupaten Musi Banyuasin.

\section{REFERENSI}

[1] S. Allwinkle and P. Cruickshank, "Creating smart-er cities: An overview," J. urban Tecbnol., vol. 18, no. 2, pp. 1-16, 2011.

[2] U. Ependi, F. Panjaitan, and H. Hutrianto, "System Usability Scale Antarmuka Palembang Guide Sebagai Media Pendukung Asian Games XVIII," J. Inf. Syst. Eng. Bus. Intell., vol. 3, no. 2, p. 80, 2017, doi: 10.20473/jisebi.3.2.80-86.

[3] H. Haris, "Metodologi Penelitian Kualitatif untuk Ilmu Psikologi." Jakarta: Salemba Humanika, 2015.

[4] M. S. HUDA, "Implementasi Metode Amsilati Dalam Pembelajaran Bahasa Arab di Pondok Pesantren Darul Amanah." Universitas Islam Sultan Agung, 2019.

[5] F. Purwaningtias and U. Ependi, "Pengujian Usability Website Pondok Pesantren Qodratullah Menggunakan System Usability Scale," J. Sains dan Inform., vol. 6, no. 1, pp. 34-43, 2020.

[6] D. Komalasari and M. Ulfa, "Pengujian Usability Heuristic Terhadap Perangkat Lunak Pembelajaran Matematika," MATRIK J. Manajemen, Tek. Inform. dan Rekayasa Komput., vol. 19, no. 2, pp. 257-265, 2020.

[7] U. Ependi, F. Panjaitan, and F. Syakti, "Pengembangan Aplikasi Mobile Travel Guide pada Provinsi Sumatera Selatan," J. Teknol. Inf. dan Ilmu Komput., vol. 7, no. 3, pp. 607-618, 2020.

[8] B. Pudjoatmodjo and R. Wijaya, "Tes Kegunaan (Usabilty Testing) Pada Aplikasi Kepegawaian Dengan Menggunakan System Usabilty Scale (Studi Kasus: Dinas Pertanian Kabupaten Bandung)," SEMNASTEKNOMEDIA ONLINE, vol. 4, no. 1, pp. 2-9, 2016.

[9] U. Ependi, T. B. Kurniawan, and F. Panjaitan, "System Usability Scale Vs Heuristic Evaluation: A Review," Simetris J. Tek. Mesin, Elektro dan Ilmu Komput., vol. 10, no. 1, pp. 65-74, 2019. 